\title{
Influence of Paclobutrazol on Shoot Growth and Flowering in a High-density Pecan Orchard
}

\author{
Haijun $\mathrm{Zhu}^{1,3}$ and Eric T. Stafne ${ }^{2}$
}

\begin{abstract}
AdDitional INDEX wORDs. Carya illinoinensis, pistillate inflorescences, size controlling

Summary. Paclobutrazol (PBZ) was applied to 6-year-old pecan (Carya illinoinensis $)$ trees as a basal trunk drench $\left(0,30,90\right.$, and $150 \mathrm{mg} \cdot \mathrm{cm}^{-2}$ trunk crosssectional area) in Dec. 2012. Terminal shoot growth was retarded for 1 year after a single application of PBZ. The total number of current season shoots showed a significant increase with 30 - and $90-\mathrm{mg} \cdot \mathrm{cm}^{-2} \mathrm{PBZ}$ treatments. After PBZ application at 30,60 , and $90 \mathrm{mg} \cdot \mathrm{cm}^{-2}$, the percentage of very short shoots $(<5 \mathrm{~cm})$ was $32.3 \%, 36.3 \%$, and $32.3 \%$, respectively, compared with $22.4 \%$ on control trees; the percentage of short shoots $(5-15 \mathrm{~cm})$ increased to $36.0 \%, 38.1 \%$, and $43.5 \%$, respectively. The percent of long shoots $(>30 \mathrm{~cm})$ was decreased to $7.4 \%, 5.1 \%$, and $7.6 \%$, respectively, after PBZ application, compared with $18.7 \%$ with control. Shoots varying from 5 to $30 \mathrm{~cm}$ in length accounted for at least $63.3 \%$ of all pistillate inflorescences the following spring.
\end{abstract}

$\mathrm{D}$ ue to the strong vegetative nature of relatively young pecan trees and the absence of dwarfing rootstocks or cultivars, controlling tree size is a major problem in high-density pecan orchards. Paclobutrazol, an effective inhibitor of gibberellin biosynthesis, offers a superior method of tree size control of pecan compared with traditional and generally unsuccessful pruning or hedging methods (Sparks, 1979). Previous research indicated the strong effect of PBZ on pecan seedlings grown in a greenhouse (Marquard, 1985; Wood, 1984), young trees in the field (Andersen and Aldrich, 1987; Gash and David, 1989; Wood, 1986, 1988a), and large pecan trees (Wood, 1988b; Worley et al., 1996). However, there are differential cultivar responses depending on tree size and age and on the balance between vegetative and reproductive growth (Gash and David, 1989; Wood, 1988a; Worley et al., 1996).

Received for publication 11 Dec. 2018. Accepted for publication 1 Feb. 2019.

Published online 25 March 2019

${ }^{1}$ Jiangsu Academy of Agricultural Sciences, Institute of Pomology, 50 Zhongling Street, Nanjing, Jiangsu 210014, China

${ }^{2}$ Coastal Research and Extension Center, Mississippi State University, Poplarville, MS 39470

${ }^{3}$ Corresponding author. E-mail: zhuhaijun@jaas.ac. $\mathrm{cn}$.

This is an open access article distributed under the CC BY-NC-ND license (https://creativecommons.org/ licenses/by-nc-nd/4.0/).

https://doi.org/10.21273/HORTTECH04241-18
A well-maintained carbohydrate and nitrogen balance within certain levels is essential for pecan flower formation (Gourley and Howlett, 1941). Terminal growth is related to the amount of stored carbohydrates and is an outward expression of the nutritional and physiological condition of the tree (Crane, 1930; Gossard, 1954; Sparks and Brack, 1970). It is also the most common characteristic observed by growers, who associate it with tree vigor and nutrition. There can be a large variation in shoot growth on the same tree or different trees. Old trees tend to produce short shoots while young trees produce longer shoots (Crane, 1930). In mature trees, longer shoots produce more leaf area and carbohydrates (Sparks, 1969), but excess vegetative growth resulted in little or no blossoming and nut production (Gossard, 1954). Trees with short and weak shoots were less likely to fruit the following year than shoots within the optimal growth range for fruiting. Heavy nut production is associated with shoots of medium length (Isbell, 1928).

Different cultivars have a wide shoot-length range for optimal fruit production (Amling, 1959; Isbell,
1928). The optimal shoot length ranges for fruiting in 'Western Schley', 'Burkett', 'Stuart', and 'Success' were on shoots 4 to 15,4 to 18,4 to 9 , and 2.5 to 8 inches, respectively (Taylor, 1959). Gossard (1954) suggested that the best range for terminal growth was 4 to 8 inches. The general recommendation for pecan fertilization is to keep annual terminal growth on mature bearing pecan trees to 4 to 8 inches long. A significant positive relationship was found between yield and percentage of fruiting shoots (Sparks and Heath, 1972; Sparks, 1975). Young pecan trees usually produce few lateral branches due to aggressive vegetative growth, which contributes to relatively low yields (Thompson, 1981). Increased lateral branching may increase the potential number of sites for nut initiation (Andersen and Aldrich, 1987). Chemical applications (Malstrom and McMeans, 1977, 1978) and pruning (Kuykendall and Tate, 1970) may be potential methods to promote lateral shoots.

This experiment was carried out to 1) evaluate the effects of paclobutrazol on inhibiting pecan vegetative growth and increasing the number of different shoot lengths and 2) investigate the relationship between shoot length and number of pistillate inflorescences.

\section{Materials and methods}

Six-year-old 'Mahan' trees (Lulang Pecan Ranch, Nanjing, China; lat. $31.78^{\circ} \mathrm{N}$, long. $\left.118.62^{\circ} \mathrm{E}\right)$ spaced $5 \times 7.5 \mathrm{~m}$ were used in this study. The site has a freeze-free growing period of $230 \mathrm{~d}$ with annual precipitation of $1053 \mathrm{~mm}$. Trees appeared to be crowding as limbs began to intermesh within rows.

Paclobutrazol was applied to trees via soil drench (rates of 0,30 , 90 , and $150 \mathrm{mg} \cdot \mathrm{cm}^{-2}$ trunk crosssectional area) in Dec. 2012. The four treatments were initially applied in a randomized complete block design with three-single tree replications. Four types of shoots were defined

\begin{tabular}{llll}
\hline $\begin{array}{l}\text { Units } \\
\begin{array}{l}\text { To convert U.S. to SI, } \\
\text { multiply by }\end{array}\end{array}$ & U.S. unit & SI unit & $\begin{array}{l}\text { To convert SI to U.S., } \\
\text { multiply by }\end{array}$ \\
\hline 0.3048 & $\mathrm{ft}$ & $\mathrm{m}$ & 3.2808 \\
2.54 & inch(es) & $\mathrm{cm}$ & 0.3937 \\
25.4 & inch $(\mathrm{es})$ & $\mathrm{mm}$ & 0.0394 \\
$4.3942 \times 10^{3}$ & $\mathrm{oz} / \mathrm{inch}^{2}$ & $\mathrm{mg} \cdot \mathrm{cm}^{-2}$ & $2.2757 \times 10^{-4}$
\end{tabular}


Table 1. Number of shoots in different length categories in 6-year-old pecan tree canopies after a single application of paclobutrazol $(\mathrm{PBZ})$ at 30,90 , and $150 \mathrm{mg} \cdot \mathrm{cm}^{-2}$ trunk cross-sectional area.

\begin{tabular}{|c|c|c|c|c|c|}
\hline \multirow{3}{*}{$\begin{array}{l}\text { PBZ } \\
\left(\mathrm{mg} \cdot \mathrm{cm}^{-2}\right)^{\mathrm{z}}\end{array}$} & \multicolumn{4}{|c|}{ Shoot length $(\mathrm{cm})^{\mathrm{z}}$} & \multirow{3}{*}{$\begin{array}{c}\text { Total shoots } \\
(\text { mean no. } \pm \text { SE })\end{array}$} \\
\hline & $<5$ & $5-15$ & $15-30$ & $>30$ & \\
\hline & \multicolumn{4}{|c|}{ Shoots [mean no. \pm SE (\%)] } & \\
\hline 0 & $69 \pm 6 b^{y}(22.4 \%)$ & $100 \pm 0 b(32.7 \%)$ & $80 \pm 9 b(26.3 \%)$ & $57 \pm 6$ a $(18.7 \%)$ & $306 \pm 20 b$ \\
\hline 30 & $131 \pm 7 \mathrm{a}(32.3 \%)$ & $146 \pm 6$ a $(36.0 \%)$ & $98 \pm 10 \mathrm{a}(24.3 \%)$ & $30 \pm 6 b(7.4 \%)$ & $405 \pm 4 \mathrm{a}$ \\
\hline 90 & $104 \pm 7 \mathrm{a}(36.3 \%)$ & $109 \pm 8 b(38.1 \%)$ & $59 \pm 3 b(20.5 \%)$ & $15 \pm 4 b(5.1 \%)$ & $285 \pm 8 b$ \\
\hline 150 & $119 \pm 12 \mathrm{a}(32.3 \%)$ & $160 \pm 8$ a $(43.5 \%)$ & $61 \pm 8 b(16.6 \%)$ & $28 \pm 4 \mathrm{~b}(7.6 \%)$ & $367 \pm 10 \mathrm{a}$ \\
\hline
\end{tabular}

${ }^{\mathrm{z}} 1 \mathrm{mg} \cdot \mathrm{cm}^{-2}=2.2757 \times 10^{-4} \mathrm{oz} /$ inch $^{2}, 1 \mathrm{~cm}=0.3937$ inch.

${ }^{y}$ Different letters within a column indicate that the values are significantly different according to Duncan's multiple range test $(P<0.05)$.

for this study: 1$)$ very short shoots $(<5$ $\mathrm{cm}), 2$ ) short shoots $(5-15 \mathrm{~cm}), 3$ ) medium shoots $(15-30 \mathrm{~cm})$, and 4$)$ long shoots $(>30 \mathrm{~cm})$ (Zhang, 1979). Number of shoots of different lengths and pistillate inflorescences were counted in Apr. and May 2014 , respectively. Data were subjected to analysis of variance and Duncan's multiple range tests at $5 \%$ level using SPSS statistical software (Grad Pack 16; IBM Corp., Armonk, NY).

\section{Results and discussion}

The total number of current season shoots per tree in 2013 showed a significant increase with 30 - and $150-\mathrm{mg} \cdot \mathrm{cm}^{-2}$ PBZ treatments, but no difference with 90 $\mathrm{mg} \cdot \mathrm{cm}^{-2} \mathrm{PBZ}$ compared with the control (Table 1). Trees treated with 30,90 , and $150 \mathrm{mg} \cdot \mathrm{cm}^{-2}$ PBZ produced 405, 285, and 367 shoots, respectively, whereas the average number of shoots arising from control trees without PBZ was 306. Similarly, enhanced lateral branching was reported for PBZ-treated apple (Malus $\times$ domestica) seedlings (Swietlik and Miller, 1983) and pecan (Andersen and Aldrich, 1987). Yield of pecan orchards is related to percentage of fruiting shoots (Sparks, 1975), and the number of shoots, especially fruiting shoots, is an important indicator of future nut production potential.

Reducing vegetative growth of shoots can lead to their transformation into fruiting shoots. In this study, terminal growth was retarded during the first year after a single PBZ treatment. The percent of expanding shoots decreased to $7.4 \%, 5.1 \%$, and $7.6 \%$ for 30,90 , and $150 \mathrm{mg} \cdot \mathrm{cm}^{-2}$, respectively, after $\mathrm{PBZ}$ application compared with $18.7 \%$ with control. This is because young 'Mahan' trees

Table 2. Pistillate inflorescences of 6-year-old pecan tree formed the following spring after a single application of paclobutrazol (PBZ) at 30, 90, and 150 $\mathrm{mg} \cdot \mathrm{cm}^{-2}$ trunk cross-sectional area.

\begin{tabular}{|c|c|c|c|c|}
\hline \multirow{3}{*}{$\begin{array}{l}\text { PBZ } \\
\left(\mathrm{mg} \cdot \mathrm{cm}^{-2}\right)^{\mathrm{z}}\end{array}$} & \multicolumn{4}{|c|}{ Shoot length $(\mathrm{cm})^{\mathrm{z}}$} \\
\hline & $<5$ & $5-15$ & $15-30$ & $>\mathbf{3 0}$ \\
\hline & \multicolumn{4}{|c|}{ Pistillate inflorescences formed $[$ mean \pm SE (no.) $]$} \\
\hline 0 & $2.7 \pm 0.05 \mathrm{c}^{\mathrm{y}}$ & $4.1 \pm 0.14 \mathrm{~d}$ & $4.7 \pm 0.06 \mathrm{c}$ & $2.4 \pm 0.04 \mathrm{a}$ \\
\hline 30 & $4.2 \pm 0.12 \mathrm{a}$ & $6.6 \pm 0.10 \mathrm{a}$ & $7.8 \pm 0.16 \mathrm{a}$ & $1.6 \pm 0.10 \mathrm{c}$ \\
\hline 90 & $3.7 \pm 0.08 b$ & $6.3 \pm 0.05 b$ & $7.4 \pm 0.18 \mathrm{a}$ & $2.2 \pm 0.15 b$ \\
\hline 150 & $3.8 \pm 0.09 \mathrm{~b}$ & $5.9 \pm 0.06 c$ & $6.8 \pm 0.10 \mathrm{~b}$ & $2.7 \pm 0.22 \mathrm{a}$ \\
\hline
\end{tabular}

${ }^{\mathrm{z}} \mathrm{l} \mathrm{mg} \cdot \mathrm{cm}^{-2}=2.2757 \times 10^{-4} \mathrm{oz} /$ inch $^{2}, \mathrm{l} \mathrm{cm}=0.3937$ inch.

${ }^{\mathrm{y}}$ Different letters within a column indicate that the values are significantly different according to Duncan's multiple range test $(P<0.05)$

have naturally high vigor and mainly produce long and expanding shoots. Also, PBZ increased the proportion of short and very short shoots. Percent of very short shoots with PBZ application at 30,90 , and 150 $\mathrm{mg} \cdot \mathrm{cm}^{-2}$ was $32.3 \%, 36.3 \%$, and $32.3 \%$, which was significantly higher than $22.4 \%$ very short shoots produced on control trees. Percent of short shoots increased with increasing $\mathrm{PBZ}$ rate at 30 and $150 \mathrm{mg} \cdot \mathrm{cm}^{-2}$ but not at the $60-\mathrm{mg} \cdot \mathrm{cm}^{-2} \mathrm{PBZ}$ rate.

PBZ treatments also influenced pistillate inflorescences formed the following spring. The number of pistillate inflorescences formed on shoots under $30 \mathrm{~cm}$ increased significantly for all PBZ treatments (Table 2). For shoots under $30 \mathrm{~cm}$, lower rate PBZ treatments produced more pistillate inflorescences than $\mathrm{PBZ}$ at 150 $\mathrm{mg} \cdot \mathrm{cm}^{-2}$ and the control. It appears that the pistillate flowers that initiated from different shoots in length have different responses to PBZ applications.

Table 2 shows that the length of shoots was related to pistillate flowering. A large percentage of pistillate inflorescences initiated on shoots varying from 5 to $15 \mathrm{~cm}$ in length. This result is consistent with previous research (Gossard, 1954; Taylor,
1959). Shoot growth is related to the amount of carbohydrates stored (Sparks and Brack, 1970). Longer shoots produce more leaf area and carbohydrates (Sparks, 1969), as well as more pistillate flowers on a shoot (Sparks, 1975). However, shoots greater than $30 \mathrm{~cm}$ in our study formed few pistillate flowers. Therefore, carbohydrate storage does not appear to explain the few pistillate flowers arising from longer shoots. Other researchers noted that carbohydrates appeared to be an important factor determining the ability to flower (Smith et al., 1986), rather than controlling flower induction on individual shoots (Rohla et al., 2005). A similar mechanism might explain why shoot lengths were negatively related to pistillate inflorescences in this study. Shoot growth potential and number of female blossoms are reduced with the diminishing rate of carbohydrate storage (Arreola-Avila et al., 2006). This is consistent with results from shoots under $5 \mathrm{~cm}$ in length that formed few pistillate inflorescences.

As is demonstrated in previous studies (Wood, 1987, 1988a), nonuniform control of tree growth from PBZ applications was still noted in the field. These escaped lammas shoots, 
greater than $100 \mathrm{~cm}$ long, especially on upper parts of the tree canopy, may have been due to either nonuniform uptake of PBZ by trees or the high vigor nature of 'Mahan'. Further work is needed to refine the optimal rate of $\mathrm{PBZ}$ and to address suitable methods to avoid overtreatment.

\section{Conclusions}

Because of the early production and quicker returns, many growers in China prefer high-density planting systems that have the potential to break even in 6 to 7 years compared with 10 to 12 years for traditional systems (Zhu, 2018). PBZ application appears to be a method to control pecan tree size and is superior to pruning methods that require a significant amount of labor resources and also results in temporary loss of production. The yield is expected to increase as more pistillate inflorescences produced. Unfortunately, we were not able to collect the yield data because of the owner's preharvesting. As is shown in this study, greater than $35 \%$ pistillate inflorescences were produced on shoots 15 to $30 \mathrm{~cm}$ long. Thus, maintaining 'Mahan' tree shoot growth within this range tends to be optimal shoot length range for young tree management.

\section{Literature cited}

Amling, H.J. 1959. Shoot growth and pecan fruiting. Proc. Southeastern Pecan Growers Assn. 52:45-48.

Andersen, P.C. and J.H. Aldrich. 1987. Effect of soil-applied paclobutrazol on 'Cheyenne' pecans. HortScience 22: 79-82.

Arreola-Avila, J., E. Herrera-Aguirre, R. Trejo-Calzada, A. Flores-Hernández, R. Parra-Quezada, and A. Borja-de la Rosa. 2006. Sunlight availability and nut production after thinning of pecan trees. Rev. Chapingo Ser. Hort. 12:177-181.

Crane, H.L. 1930. Terminal growth in relation to fruiting in the pecan. Natl. Pecan Assn. Bul. 29:24-32.
Gash, D. and I. David. 1989. Paclobutrazol effect on growth and cropping of pecan trees. Acta Hort. 239:301-304.

Gossard, A.C. 1954. Growth and fertilization of pecan trees in relation to regularity of bearing. Proc. Oklahoma. Pecan Growers Assn. 24:14-22.

Gourley, J.H. and F.S. Howlett. 1941. Modern Fruit Production. Macmillan, New York, NY.

Isbell, C.L. 1928. Growth studies of the pecan. Alabama Agr. Expt. Sta. Bul. 226.

Kuykendall, J.R. and H.F. Tate. 1970. Pecan pruning experiments in Arizona. Proc. Southeastern Pecan Growers Assn. 63:42.

Malstrom, H.L. and J.L. McMeans. 1977. A chemical method of pruning young pecan trees. HortScience 12:68-69.

Malstrom, H.L. and J.L. McMeans. 1978. Chemical pruning young pecan trees. Pecan Qrtly 12(1):23-24, 26, 28.

Marquard, R.D. 1985. Chemical growth regulation of pecan seedlings. HortScience 20:919-921.

Rohla, C.T., M.W. Smith, and N.O. Maness. 2005. Effects of cluster size and shoot type on characteristics of pecan nuts. HortScience 40:1300-1303.

Smith, M.W., R.W. McNew, P.L. Ager, and B.C. Cotton. 1986. Seasonal changes in the carbohydrate concentration in pecan shoots and their relationship to flowering. J. Amer. Soc. Hort. Sci. 111: 558-561.

Sparks, D. 1969. Some characteristics of shoot growth of pecan trees and their implications to yields. Proc. Southeastern Pecan Growers Assn. 62:55-75.

Sparks, D. 1975. The alternate fruit bearing problem in pecans. Proc. Northern Nut Growers Assn. 65:145-157.

Sparks, D. 1979. Physiology-site, growth, flowering, fruiting, and nutrition, p. 211239. In: R.A. Jaynes (ed.). Nut tree culture in North America. Northern Nut Growers Assn., Hamden, CT.

Sparks, D. and C.E. Brack. 1970. Effect of removing leaves and fruit on return bloom and fruit set on the Stuart pecan. Proc.
Southeastern Pecan Growers Assn. 63: 69-71.

Sparks, D. and J.L. Heath. 1972. Pistillate flower and fruit drop of pecan as a function of time and shoot length. HortScience 7:402-404.

Swietlik, D. and S.S. Miller. 1983. The effect of paclobutrazol on growth response to water stress of apple seedlings. J. Amer. Soc. Hort. Sci. 108:1076-1080.

Taylor, G.G. 1959. The relation of terminal growth to fruiting in pecans. MS Thesis, Oklahoma State Univ., Stillwater.

Thompson, T.E. 1981. Pecan breeding prospects. Pecan Qrtly 15:4-11.

Wood, B.W. 1984. Influence of paclobutrazol on selected growth and chemical characteristics of young pecan seedlings. HortScience 19:837-839.

Wood, B.W. 1986. Influence of paclobutrazol (PP-333), Flurprimidol (EL-500) and Ortho XE-1019 (Chevron) growth retardants on growth and selected chemical and yield characteristics of Carya illinoinensis. Acta Hort. 179:287-288.

Wood, B.W. 1987. Control of pecan tree size by bioregulating chemicals. Proc. Southeastern Pecan Growers Assn. 80: 40-45.

Wood, B.W. 1988a. Paclobutrazol suppresses shoot growth and influences nut quality and yield of young pecan trees. J. Amer. Soc. Hort. Sci. 113:374-377.

Wood, B.W. 1988b. Paclobutrazol suppresses vegetative growth of large pecan trees. HortScience 23:341-343.

Worley, R.E., B.G. Mullinix, and J.W. Daniel. 1996. Selective limb pruning, tree removal, and paclobutrazol growth retardant for crowding pecan trees. Scientia Hort. 67:79-85.

Zhang, W.C. 1979. Research methodology in pomology. China Agriculture Press, Beijing, China.

Zhu, H.J. 2018. Challenges for the expanding pecan industry in China. Pecan South 51(9):16-23. 